\title{
Study on Applying Chinese Excellent Culture in the Ideological and Political Education in Colleges
}

\author{
Jialiang Cao \\ Qiqihar Medical University, Marxist College, Qiqihar, Heilongjiang, 161006
}

Keywords: Ideological and Political Education, Chinese Excellent Culture, Leaning and Application

\begin{abstract}
Chinese excellent traditional culture contains a wealth of educational resources, ideological and political education for college students can provide an inexhaustible supply of ideological essence and educational philosophy. In the process of integrating excellent Chinese traditional culture into the ideological and political education in colleges, it is important to follow the important principle of integrating and take effective measures to promote the excellent Chinese traditional culture into the ideological and political education in colleges to further enhance the attractiveness and effectiveness of ideological and political education in colleges.
\end{abstract}

\section{Introduction}

The rapid development of China today, by leaps and bounds. The CPC Central Committee with Comrade Xi Jinping as the core proposes the overall layout of building socialism with Chinese characteristics, that is, the "five in one" thinking of economic construction, political construction, cultural construction, social construction and ecological construction. China has become the second largest economy in the world, with the volume of import and export trade ranking first in the world, being the highest in the world in many fields such as coal and steel, and the renminbi is included in the currency basket of special drawing rights (SDR), making it the major component of international trade settlement One of the currencies, and the growing use of the scope of the RMB as the world's major currency has laid a solid foundation for the goal. China's political system has become more stable and mature. The "four comprehensive" strategic layout put forward by the Central Party Committee has been adhered to by carrying out its reform and opening up, adhering to the principle of governing the country according to law, resolutely and strictly administering the party, and striving for the full realization of a well-to-do society and "two hundred and one hundred years." The goal of "Chinese Dream" provides a solid guarantee. With the strength of China's national strength, the international influence of our country has become increasingly apparent and its contribution to the world has become more apparent. The Voice of China has been heard continuously and clearly everywhere in the world. At the same time, China's development faces many challenges both at home and abroad. Internationally, the trend of economic globalization and world integration is deepening day by day. The exchanges, integration and reorganization of politics, militaries and cultures in various countries are deepening constantly. The world structure is undergoing tremendous changes. The pattern of the old world is gradually disintegrating. The new as the world structure has not yet been established, the entire international order is in a complex and volatile situation. At home, after nearly 40 years of reform and opening up, earth-shaking changes have taken place in Chinese society. China's reform of the social and economic systems has entered the deep-water area. Various deep-rooted social conflicts have caused China's shipping vessels to face many undercurrents and social changes Such phenomena as social disorder, moral decline, official corruption and lack of civilization, as well as the frequent occurrence of food safety, medical disputes, telecommunications fraud and environmental pollution, have a direct impact on the harmonious development of society [1]. 


\section{Excellent traditional culture and ideological and political education in colleges}

Chinese traditional culture can be summed up many features, but I think there are two characteristics of the most prominent. First, Chinese traditional culture has a long history. Different from the ancient Greek and Roman culture, more different from the ancient Egyptian culture, the ancient Babylonian culture, the Chinese traditional culture from the yellow to the late Qing Dynasty, including ethnic minorities during the Central Plains, the introduction of Buddhist culture, traditional Chinese culture for thousands of years from Without interruption, but without extinction, on the contrary, it assimilates the cultures of ethnic minorities and assimilates foreign cultures. Therefore, it is a dynamic system of inheritance. Second, Chinese traditional culture is profound and profound. Combined with various ideas and opinions, but in the course of its evolution, a cultural system centered mainly on Huaxia national culture and centered on Confucian culture was formed. In the process of development, Chinese traditional culture is a whole cultural system that is compatible with and integrated with each other because various points of view play with each other, draw on each other's strengths and learn from each other's strengths [2].

First, in terms of values. Ideological and Political Education in Universities Based on Marxism. Through the sinicization of Marxism, Marxism has become part of Chinese culture and Chinese civilization. One of the important contents and components of the sinicization of Marxism is to combine Marxism with Chinese history and Chinese traditional culture. This not only emphasizes the necessity of integrating traditional culture into ideological and political education in universities, but also integrates traditional culture into ideological and political education Education provides theoretical support. In the report of the 18th CPC National Congress, the basic content of the socialist core values is summed up in 24 words. It is not only the primary task of ideological and political education in fostering and practicing the socialist core values but also the responsibility of the whole society. The values contained in the excellent Chinese traditional culture have many similarities with the socialist core values. The socialist core values emphasize the values of "civilization," "harmony," "fairness," "patriotism," "honesty," and "friendship." Similarly, Chinese traditional culture advocates collectivism and views patriotism as the most basic character of individuals. It pursues harmony and unity among people, people, society and people and nature. It emphasizes ethics and emphasizes the importance of honesty and integrity. It advocates "Loyalty and forgiveness", advocating the principle of doing good with others. Many of these values are in essence compatible with the socialist core values. Liu Yunshan pointed out: "To cultivate and practice the core values of socialism, we must take excellent traditional culture as the foundation, add cultural connotations, realize cultural concern, and strive to be cultural people and educate people." Therefore, traditional It is both necessary and feasible to integrate culture into college ideological and political education from the perspective of values [3].

Second, in terms of educational goals. The ideological and political education in Colleges refers to the purposeful cultivation and education of college students in accordance with the requirements of our country's social development so that they can grow up to be qualified qualified personnel in line with the needs of our society. Specifically speaking, they are loving their motherland politically and upholding the leadership of the party. They should establish a scientific world outlook, outlook on life and values in their thinking so that the majority of young students will have good moral qualities, healthy psychological qualities and sound independent personalities. The goals of ideological and political education in Colleges have many similarities with Chinese traditional culture. First of all, traditional culture pays attention to cultivating people's ethics and morality as a fundamental basis for one's social standing. At the beginning of the "University", it proposed that "the way of the university, in a clear morality, stop at perfection," emphasizes the importance of noble morality and places human morality first. Second, traditional culture requires that individuals have a collective view of collectivism, love their country, love their own people, love their loved ones, and love their friends. Third, traditional culture requires people to have a persevering character and to save "awe-inspiring spirit" through personal cultivation so as to achieve self-cultivation in good faith. The commonalities of these educational goals make the integration of 
the two more convenient and efficient [4].

\section{Excellent traditional culture into the ideological and political education in colleges}

The traditional culture and education of undergraduates should generally start from primary school. The study of traditional cultural contents and spirits should be gradually carried out in the courses of Chinese and history of primary and secondary schools. In the university stage, Colleges continue to carry out traditional culture and education for college students. One of the prerequisites for achieving the desired result is to study what traditional culture and education students have accepted in primary and secondary schools, and understand that students have studied in primary and secondary schools Traditional culture, so that we can effectively connect with the traditional culture of primary and secondary schools in teaching materials and teaching contents, and avoid the separation of traditional culture education at Colleges from the traditional culture education at primary and secondary schools. For example, we can expand and expand the content of this part in the traditional culture and education of the university, and can do a special study or lecture on "The Analects of Confucius." Everyone's understanding of Mencius is obviously not as good as that of Mencius Confucius, then you can add the main ideas of Mencius and life stories to the teaching content; to learn Wen Tianxiang works in high school, in the university stage we can continue to study Wen Tianxiang, learn from his "righteous song" to cultivate the health of college students Personality. This lecture content so that students are familiar with, intimacy, help to stimulate students interest in learning and enthusiasm. In addition, we should keep up with the times, pay attention to the popular traditional culture in our society, and screen them to add to our teaching activities. In the past two years, the court drama was very popular with everyone. The series such as "Zhen Huan Chuan" and "Han Yue Biography" were hit in succession by various major TV stations and their ratings were high. We can take this opportunity to make use of the historical background of the drama to tap the excellent traditional and cultural spirit in which the students are good and educate the students on traditional culture. For example, the historical background of the "Mochizuki Biography" is the period of the Spring and Autumn Period and the Warring States Period. During this period, the fierce competition between the two places led to the prosperity and development of the Chinese traditional culture. We can use the "Mochizuki Biography" as an entry point for students to introduce The forming process and the core views held by the hundreds of philosophers show the students profound and long history of traditional Chinese culture so that students can understand the development of traditional culture so as to achieve the educational goal of popularizing traditional culture and cultivating the pride of college students [5].

Classroom teaching is the main channel of college education. When we carry out the traditional culture education for college students, we should give full play to the role of the main channel of classroom teaching, and increase the emphasis on the setting of traditional culture courses. At the same time, we should also strengthen the construction of relevant teaching materials. In terms of curricula, schools should increase the proportion of traditional culture courses. First, the establishment of specialized courses of traditional culture, such as "Introduction to Traditional Chinese Culture" and other courses, the traditional culture courses included in the ranks of compulsory courses to become a school for each major professional courses to be on. The second is to carry out traditional culture in Colleges lectures. Please traditional culture research experts and scholars for college students to explain the traditional culture, such as "university" ten, "Analects" a new interpretation and so on. Third, the part of traditional culture should be added into the related courses of ideological and political theory and various majors in Colleges. For example, ethics should be added to the traditional culture in the course of "Ideological and Moral Cultivation and Law Basics", but the methods of fragmentation in current teaching materials should be changed. Instead, a single or a single course should be devoted to systematically teaching Chinese excellent traditions Cultural content. In terms of textbook construction, traditional culture and education can learn from the practice of ideological and political education in Colleges and learn from the successful experience in the construction of teaching materials of ideological and political theory. At present, the textbook construction of ideological and political theory courses in Colleges has 
achieved some initial success. The Ministry of Education instructs the preparation of the series of books on the teaching of ideological and political theory courses in Colleges [6], covering 4 undergraduate courses of ideological and political theory. At the same time, relevant departments organized the preparation of teachers' reference materials, student supplementary books, teaching case sets and other related reference books and auxiliary teaching books. In addition, the Ministry of Education has also directed the compilation of "Teaching Libraries of Ideological and Political Theory Courses in Colleges", making full use of online resources for ideological and political education. All these measures have played a very good role in the demonstration of traditional culture and education in Colleges, and the traditional culture and education in Colleges should also increase their strength in the construction of teaching materials. First of all, the relevant departments should organize their efforts to screen and integrate the existing traditional culture teaching materials, publish unified textbooks for traditional culture and education in universities and standardize traditional culture and education. At the same time, it is necessary to enrich the contents of excellent Chinese traditional culture in different professional education. For students of different majors, we should make appropriate adjustments to traditional culture course materials and incorporate the contents related to professional characteristics so as to make them targeted. Secondly, the traditional culture and education of Colleges should make full use of advanced network technologies, compile their own online textbooks that belong to traditional culture and education, and spread them through web pages, Weibo and WeChat public numbers in order to strengthen the construction of traditional cultural textbooks in many aspects purpose.

\section{Conclusions}

Chinese excellent traditional culture contains a wealth of educational resources, ideological and political education for college students can provide an inexhaustible supply of ideological essence and educational philosophy. In the process of integrating excellent Chinese traditional culture into the ideological and political education in Colleges, we must follow the important principle of integrating, critically integrating, conscientiously integrating, and integrating with each other. We should take effective measures to promote the excellent Chinese traditional culture into the ideological and political education in Colleges to further enhance the attractiveness and effectiveness of ideological and political education in Colleges.

\section{Acknowledgements}

Qiqihar Philosophy and Social Sciences Planning Project "young students recognition of our outstanding culture" (QSX2016-14JL)

\section{References}

[1] Li Qijie. On Ideological and Political Education in Institutions of Higher Learning in Globalization [J]. Theory and Practice in Education, 2012, (12). 35 36.

[2] Xu Jinzhao. Analysis and Reform Innovation of Ideological and Political Education in Colleges [J]. Hubei Social Sciences, 2010, (8). 186 188.

[3] Jing Yuan. Opportunities and Challenges of Ideological and Political Education in Colleges under the Network Environment [J]. Theory and Practice in Education, 2010, (36).29 31.

[4] Liang Miaorong. Challenges and Countermeasures of Ideological and Political Education in Colleges in New Media Environment [J]. Party Building and Ideological Education in Schools, 2013, (12). 68 69.

[5] Li Guojuan. The theoretical thinking and practical logic of strengthening Chinese excellent traditional culture education in Colleges [J]. Research in Ideology, 2015, (4).64 69.

[6] Ji Xiaorong. Relying on Traditional Culture to Strengthen Ideological and Political Education in Colleges [J]. Educational Theory and Practice, 2015,35 (3).27 28. 